\title{
Morphological and molecular changes induced in the callus culture of peanut (Arachis hypogaea L.) after $\gamma$-irradiation of ${ }^{137} \mathrm{Cs}$
}

\author{
Elena Hlinková ${ }^{1}$ and Milan Bobák ${ }^{2}$ \\ Department of Genetics ${ }^{1}$, Department of Plant Physiology ${ }^{2}$, Faculty of Natural Sciences, Comenius University, \\ Bratislava, Slovakia
}

Received $6^{\text {th }}$ June 2003.

Revised $4^{\text {th }}$ February 2004.

Published online $10^{\text {th }}$ April 2004.

\begin{abstract}
Summary
Calli cultures of higher plants cultivated for a long-time in vitro conditions are characterized by higher resistance to $\gamma$-irradiation. The causes of this resistance are both genetic and epigenetic induced factors including cultivation conditions and exogenous growth regulators.

The $\gamma$-irradiation of ${ }^{137} \mathrm{Cs}$ with the doses $\mathrm{D}=1,5,10,100$ and 500 Gy applied on the partially synchronized peanut calli cultures showed that small doses $\mathrm{D} \in<1,5>$ Gy had a slight stimulation effect on the growth processes. Inhibition of the growth began for the dose $\mathrm{D} \geq 100$ Gy. Dose $\mathrm{LD}_{50}$ reached $250 \pm 50$ Gy. Necrose was not detected but cells of calli cultures changed their color. Stimulating doses $\mathrm{D} \in<1,10>$ Gy of $\gamma$-irradiation decreased morphological polymorphism of cells and nuclei. Gene expression was changed in the first minutes after irradiation. The spectrum of proteins and polypeptides synthesized de novo changed depending on the doses used. Protein Hsp60 was registered only for doses $\mathrm{D}=100$ and $500 \mathrm{~Gy}$. Proteins connected with the apoptosis pathway ( 2 21, p27, and p53) were synthesized in two waves, the first appeared between 24-48 hours after irradiation and the second appeared in the stationary growth phase. Changes in the content of GTP-binding proteins as well as auxin and cytokinin binding proteins are indicated by their participation in post-radiation repair mechanisms. The role of rad genes is discussed.
\end{abstract}

Keywords: peanut $-\gamma$-irradiation - gene expression - protein - growth processes - reparations

\section{INTRODUCTION}

The biological effects of irradiation were observed very quickly after its discovery. At the beginning of 20-century, DeSauer (In Timofeev-Resovski et al. 1968) discovered the biological effect of irradiation from the biophysical point of view. From this time radiation effects on biological systems were intensively studied. The $\gamma$-radiation of ${ }^{137} \mathrm{Cs}$
$(\mathrm{E}=0.662 \mathrm{Mev}, \lambda=1.8788 \mathrm{pm}, \mathrm{LTE} \cong 0.2 \mathrm{keV} / \mu \mathrm{m})$ lost its energy in cells via Compton (ionization molecules) and photo-effect (full lost of energy). The dissipative energy of $\gamma$-quanta along their tracks in the cell creates $\delta$-electrons ionizing molecules of $\mathrm{H}_{2} \mathrm{O}$ and other cells biomacromolecules. Oxide, peroxide and other radicals of $\mathrm{H}_{2} \mathrm{O}$ changed redoxpotential on the intracellular membranes, enzyme activity and their structure conformation. Changes in 
the valence of $\mathrm{PO}_{4}{ }^{2-}$ ion effected the rate of phosphorylation and energy of diesteric bonds in DNA (Eidus 1979, Hérouart et al. 1993, Yin et al. 1998). Irradiation affected synthesis on protein $\mathrm{p} 21$ (cyklin-dependent inhibitor), p53 (apoptosis pathway) and $\mathrm{pRb}$ (Yin et al. 1999, Miao et al. 2001, Hai et al. 1997). Changes in the biosynthesis pathway of p21 protein affected transition from $\mathrm{G}_{1}$ to S-phase (Hermeking et al. 1997). Koltovaya et al. (1998) observed the inhibition of transition from $\mathrm{G}_{2}$ to $\mathrm{M}$-phase in the yeasts connected with activity of cdc-2 complex, by cell population of fibroblasts Takenaka et al. (1998) and Ross et al. (2003). The photo-effect induces single and double-strand breaks in the tertiary structure of DNA. Lesions in DNA appear to be the most important ones for the induction of chromosomal aberrations (Knehr et al. 1994, Nelms et al. 1998). Both the frequency and spectrum chromosomal aberrations depend on the radiation quality and dose. Cells with an asymmetrical exchange of aberration (dicentric and centric rings) and fragments are eliminated from the irradiated cell population during several divisions. Cells containing aberration type translocation and inversion are preserved in the irradiated cell population for a long time and they are the cause of mutation various type (Awa et al. 1978).

The reaction of plant cells from callus cultures cultivated long-term in vitro conditions, from the point of view of changes in the gene expression, have been very little studied. The aim of our work was the study the influence of ${ }^{137} \mathrm{Cs}$ irradiation on the gene expression and growth processes in the partially synchronized peanut callus culture cultivated long-term in vitro conditions.

\section{MATERIAL AND METHODS}

A four years old callus culture of peanut (Arachis hypogaea L. cv. Pronto) was derived from hypocotyls explants and cultivated on the medium MS (Murashige, Skoog 1962) with supplements NAA $(23 \mu \mathrm{M})$ and BAP $(0.5 \mu \mathrm{M})$. Callus culture from the end of the lag-phase was pretreated with cold $\left(\mathrm{T}=9^{0} \mathrm{C}\right)$ during 48 hours. The value of the $\mathrm{MI}$ at the end of the lag-phase was $1.1 \%$ and the number of diploid cells in the callus population was $\sim 65 \%$. The callus culture was irradiated in the "Svet" equipment in JINR Dubna (Russian) in sterile conditions in plastic Petri dishes (PD) without cultivation medium. Callus was irradiated with a collimated beam of $\gamma$-rays of ${ }^{137} \mathrm{Cs}(\mathrm{E}=0.662 \mathrm{MeV}$ and dose rate $0.53 \mathrm{~Gy} / \mathrm{s}$ ). The irradiation doses $\mathrm{D}=1$, 5, 10, 100 and 500 Gy were used. Irradiated callus, divided in five inoculi $\mathrm{m}_{0}=250 \pm 50 \mathrm{mg}$ per $\mathrm{PD}$, was immediately transferred to fresh cultivation medium
MS+NAA+BAP. Every dose had three independent replicas. For 28 days after irradiation (one subcultivation period) we studied changes in the growth processes, qualitative and quantitative changes in the soluble proteins and length of polymorphism in the cells and nuclei in the stationary growth phase.

\section{Growth index assay}

Every $7^{\text {th }}$ day, during 28 days of cultivation after irradiation, the callus inoculums were weighed. The growth index (GI) was calculated from the equation $\mathrm{GI}=\mathrm{m}_{\mathrm{i}} / \mathrm{m}_{0}$, where $\mathrm{m}_{\mathrm{i}}$ was the mass of irradiated inoculums in the $i^{\text {th }}$ day after irradiation and $\mathrm{m}_{0}$ was mass of the irradiated callus inoculum. The middle value of GI was counted over as an average from the five values per PD for every dose used.

\section{Isolation, quantification and separation of the soluble proteins}

Proteins were isolated from homogenized peanut callus cells into non-denatured 0.1 M Na-phosphate buffer pH7 according to Hlinková et al. (1995). The quantitative content of soluble proteins was determined by Branford's spectrocolorimetric method (Bradford 1976). Samples for SDS-PAGE were prepared according to Laemmli (1970). 1-D-SDS-PAGE of denatured proteins was carried out on the $12.5 \%$ discontinuous slab gel system according to Smith (1988). The $10 \mathrm{kDa}$ mass protein ladder Gibco BRL (Life Tech., USA) was used as a mass standard. Gels were stained with $\mathrm{AgNO}_{3}$ in our modification of the Nesterenko method (Nesterenko et al. 1994). Electrophoresis was done on the Midi Protean gel equipment of LKB Pharmacia (Uppsala Sweden). The first proteins were isolated immediately after irradiation: other isolations were done after 24, 48, 144 and 672 hours.

\section{Determination of the cells and nuclei polymorphism assay}

In the stationary growth phase $\left(28^{\text {th }}\right.$ day after irradiation) one inoculum from each variant was resuspended in the sterile $2.5 \%$ glucose solution. The length of cells and diameter nuclei were measured with a micrometer ocular on the microscope Biolar B (POZ Warszawa, Poland) and recalculated for a calibration curve of 20x objective. Statistical distribution was made for a random set of 500 cells. The selected unit interval for cell length was $30 \mu \mathrm{m}$ (diameter of young cells with 

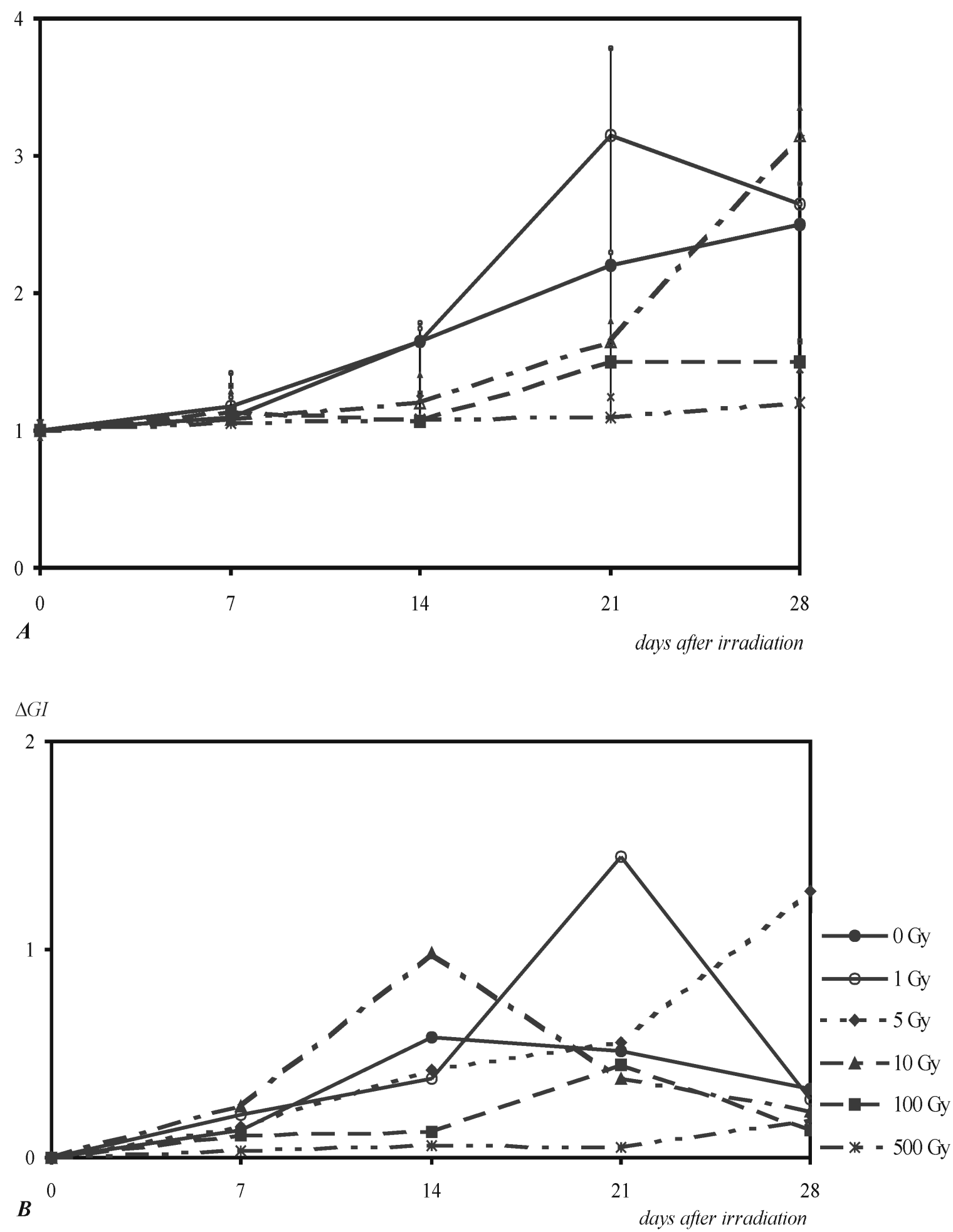

Fig.1. Influence of various doses of $\boldsymbol{\gamma}$-irradiation on the growth processes of peanut calli culture.

1A. Growth curves of four years old peanut callus culture irradiated with ${ }^{137} \mathrm{Cs}$; applied dose $\mathrm{D}=1,5,10,100,500 \mathrm{~Gy}(0$, non-irradiated control culture) during 28 days after irradiation, $\mathrm{GI}_{\mathrm{i}}=\mathrm{m}_{\mathrm{i}} / \mathrm{m}_{0}, \mathrm{i}^{\text {th }}$ day after irradiation, $\mathrm{m}_{0}$, initial masse of irradiated inoculum, $\mathrm{m}_{\mathrm{i}}$, masse of inoculum on the $\mathrm{i}^{\text {th }}$ day of cultivation. $\mathrm{GI}=\left(\Sigma \mathrm{m}_{\mathrm{i}} / \mathrm{m}_{0}\right) / 5$

1B. Changes in the mass increment of irradiated peanut inoculums in the main point of the growth curve $\left(7^{\text {th }}\right.$ day, the end of lag-phase, $14^{\text {th }}$ day, middle of the exponential phase of the growth, $21^{\text {st }}$ day, end of exponential phase of the growth, $28^{\text {th }}$ day, end of stationary growth phase $) ; \Delta \mathrm{GI}=\left(\Sigma \Delta \mathrm{m}_{\mathrm{ij}} / \mathrm{m}_{0}\right) / 5, \mathrm{j}$, the nearest day after $\mathrm{i}^{\text {th }}$ day after irradiation 
active proliferation) and for nuclei diameter we selected the interval $5 \mu \mathrm{m}$ (diameter nuclei of young diploid cells).

\section{RESULTS AND DISCUSSION}

Cytogenetic analyses of mammalian cells showed that $\gamma$-irradiation of lymphocytes, He-la cells and fibroblats in doses $\mathrm{D} \geq 1$ Gy induced numerous translocations in the chromosomes, dicentric rings and chromosome fragments. Their amount is the highest after irradiation and with prolongation of post-radiation time decreased (Govorun et al. 1998).

Calli cultures of higher plants cultivated longterm in vitro conditions have a very small mitotic index in the stationary phase of the growth, $\mathrm{MI} \leq 1 \%$ (Gacek et al. 1983, Hlinková 1989, Hlinková 1990). For this reason MI and mitotic figure is very difficult to study in such cultures. The growth index, which is the more complex parameter to quantify growth processes, gives better results for long-term cultivated calli culture in vitro conditions.

The sensitivity of plant callus cultures to mutagens is the highest to the end of lag-phase. The application of the various doses of $\gamma$-radiation of ${ }^{137} \mathrm{Cs}(\mathrm{D}=1,5,10,100$ and $500 \mathrm{~Gy})$ in this phase of the growth on the peanut callus inoculums showed that the small doses $\mathrm{D}=1,5$ and 10 Gy had a slight stimulation effect on the growth processes compared to the control value (Fig. 1A, 1B, 2).

Growth processes were inhibited by the doses $\mathrm{D} \geq 100 \mathrm{~Gy}$. The duration of the lag-phase was prolonged twice compared to the non-irradiated control (Fig. 1A). Mass increment for inhibition doses had its maximum 21 days after irradiation (Fig. 1B). This large prolongation for maximum of the mass increment of irradiated callus inoculums ( $\mathrm{D} \geq 100 \mathrm{~Gy}$ ) indicated that reparation mechanisms act very slowly and many damages induced with $\gamma$-radiation were the result of a photo-effect. This assumption indicated the possible presence of Hsp60 protein in the protein pattern samples for this doses (Tab. 1). This doses damaged intramolecular structure of DNA what is very often reason after finishing the reparation processes to induction of mutant cells.

The highest damage of DNA as well as cytoplasmatic oxygen radicals induced dose $\mathrm{D}=500 \mathrm{~Gy}$. Dose $\mathrm{LD}_{50}$ had value $250 \pm 50$ Gy (Fig. 2). Compared to doses applied to the yeast and mammalian cells used $\mathrm{D}=0.1-7 \mathrm{~Gy}$, our doses are very high (Koltovaya et al. 1998, Govorun et al. 1998, Takenaka et al. 1998, Zelinski et al. 2000, Blekkenhorst and Keraan 2003).

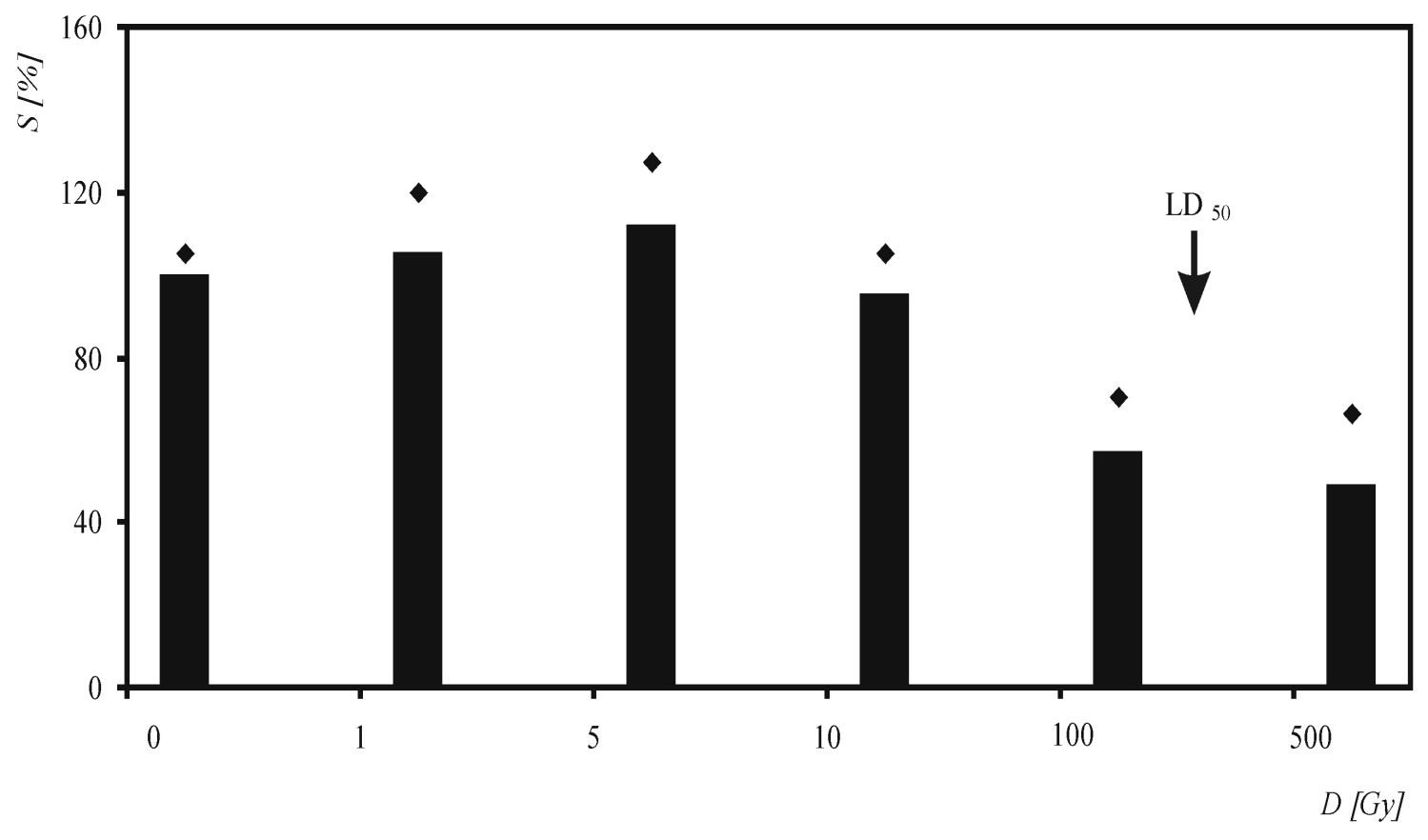

Fig. 2. Dependence of "dose-effect" for survival curve of irradiated peanut callus culture. Values were obtained to the end of the stationary phase of the growth (28 days after irradiation) and recounted to the non-irradiated control value. They represent the mean from the three independent experiments $\pm 3 \delta($ 
Damage induced by doses lower than 100 Gy were the result of $\delta$-electrons ionization energy and Compton effect. Reparations were carried out probably with gene products of early rad genes.

Protein analyses (Tab. 1) of irradiated peanut callus cells showed that immediately after irradiation patterns for callus irradiated with the dose $\mathrm{D}=1$ and 5 Gy contained de novo synthesized proteins with $\mathrm{Mr} \approx 9$ and $75 \mathrm{kDa}$ protein. Protein patterns for higher doses contained more de novo synthesized proteins. Between them we found Hsp60 protein. Cyklin-dependent kinase inhibitor p21 and protein p44 were detected for the highest dose of $\gamma$-radiation. Proteins connected with the cell death and inhibition of growth processes appeared in two waves.
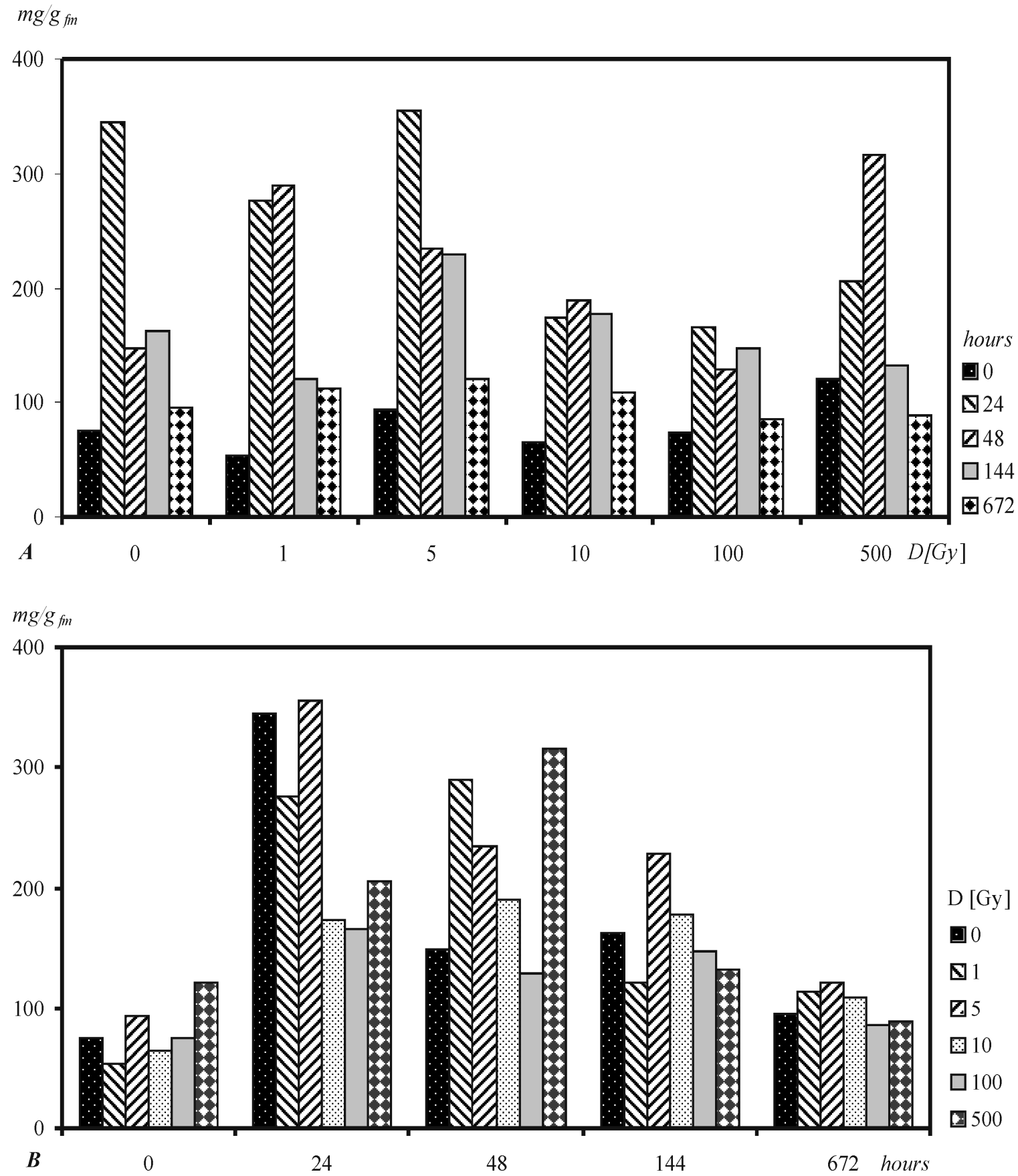

Fig. 3. Changes in the quantitative content of soluble proteins isolated from irradiated peanut callus culture. $A$ as a function of different post-radiation time, $B$ as a function of used doses of $\gamma$-irradiation 
The first was between 24-48 hours for callus irradiated $\mathrm{D} \geq 5$ Gy and second for the highest dose, 100 and 500 Gy. Proteins p34 and p36 connected with cdc-2 complex and controlled transition from $\mathrm{G}_{1} / \mathrm{S}$ phase appeared for $\mathrm{D}=10 \mathrm{~Gy}$ in the end of lagphase (144 hour after irradiation) while for the dose $\mathrm{D}=100$ Gy they were synthesized after 48 hours from irradiation. Serin-treonin kinase (p38) was detected as de novo synthesized protein after 24 hours from irradiation for the dose $\mathrm{D}=100 \mathrm{~Gy}$. This protein plays a role in transition cells from the $\mathrm{G}_{2} / \mathrm{M}$ phase and is required for the spindle assembly checkpoint mechanisms (Takenaka et al. 1998).
Quantitative changes in the content of proteins $\mathrm{p} 22$, 24, 25 (participation of auxin-binding proteins) p17, 28 and 67 (participation of cytokinin-bindings proteins) indicated the possible role of growth regulators in the reparation mechanisms. Participation of growth regulators in reparation processes is not unusual for plant callus culture. This compound controlled checkpoints for the mitotic cycle (Hlinková and Belková 1991, Kulaeva et al. 1996). Quantitative changes in the soluble proteins showed that their amount was higher in the first 24 hours after irradiation only for the dose $\mathrm{D}=5$ Gy (Fig. 3A).

Tab. 1 Changes in the protein spectra of irradiated peanut callus cultures. Analysis were done for denaturated proteins separated on $12.5 \%$ discontinual slab gels. The $10 \mathrm{kDa}$ protein ladder was used as a molecular mass standard. Gels were silver stained. Comparative analyses were done to adequate control protein patterns

\begin{tabular}{|c|c|c|c|c|c|c|}
\hline \multirow{2}{*}{$\begin{array}{c}\mathrm{D} \\
{[\mathrm{Gy}]}\end{array}$} & & $0 \mathrm{~h}$ & $24 \mathrm{~h}$ & $48 \mathrm{~h}$ & $144 \mathrm{~h}$ & $672 \mathrm{~h}$ \\
\hline & & \multicolumn{5}{|c|}{$\begin{array}{l}\text { Proteins }-\mathrm{Mr} \\
{[\mathrm{kDa}]}\end{array}$} \\
\hline \multirow[t]{2}{*}{1} & $\mathrm{~N}$ & 75 & & & & 17,9 \\
\hline & $\mathrm{m}$ & 95 & 31,24 & 24 & & $44,43,27$ \\
\hline \multirow[t]{2}{*}{5} & $\mathrm{~N}$ & 75 & $53,45,21,17$ & $\begin{array}{l}53,45,44,25 \\
21,17,14,11\end{array}$ & & $28,27,21,17,9$ \\
\hline & $\mathrm{m}$ & $95,24,22$ & 31,24 & 24 & & $\begin{array}{c}95,93,85,75 \\
44,27,23\end{array}$ \\
\hline \multirow[t]{2}{*}{10} & $\mathrm{~N}$ & 48,47 & $75,49,45$ & $\begin{array}{c}95,75,63,49 \\
44,43,27,25\end{array}$ & $38,36,34-32$ & $69,38,36,34$ \\
\hline & $\mathrm{m}$ & 70 & $43-41,24$ & 24 & 42 & 44,43 \\
\hline \multirow[t]{2}{*}{100} & $\mathrm{~N}$ & $\begin{array}{c}60,59,44,34 \\
25-24\end{array}$ & $\begin{array}{c}60,59,47,45 \\
38,36\end{array}$ & $\begin{array}{c}69,60,45,44 \\
36,34,23\end{array}$ & $\begin{array}{c}45,25,21,17 \\
15\end{array}$ & $\begin{array}{c}69,53,45,44 \\
27,25\end{array}$ \\
\hline & $\mathrm{m}$ & $95,85,65$ & $\begin{array}{c}95,85,65,49 \\
44,23\end{array}$ & $\begin{array}{l}95,85,69 \\
49-50,34\end{array}$ & $95,85,42$ & $\begin{array}{c}95,85,75,43 \\
41,31,22\end{array}$ \\
\hline \multirow[t]{2}{*}{500} & $\mathrm{~N}$ & $\begin{array}{c}60,59,44,43,33,25 \\
21,15\end{array}$ & $59,63,47,45,31$ & $\begin{array}{c}69,60,55,53,45-44 \\
25,23,21\end{array}$ & $45,25,21,1715,14$ & $53,45,44,27,25$ \\
\hline & $\mathrm{m}$ & $95,85,65,34,27$ & $\begin{array}{c}95,83,65,55,49,44 \\
41,23\end{array}$ & $95,84,69,49-50,34$ & $95,85,42$ & $\begin{array}{c}95,85,75,43,41,22 \\
17,15\end{array}$ \\
\hline
\end{tabular}

0 hour, proteins and polypeptides synthesized immediatly after irradiation

24-672 hours, time intervals after irradiation

$\mathrm{N}$, de novo synthesized proteins

$\mathrm{m}$, missing proteins 

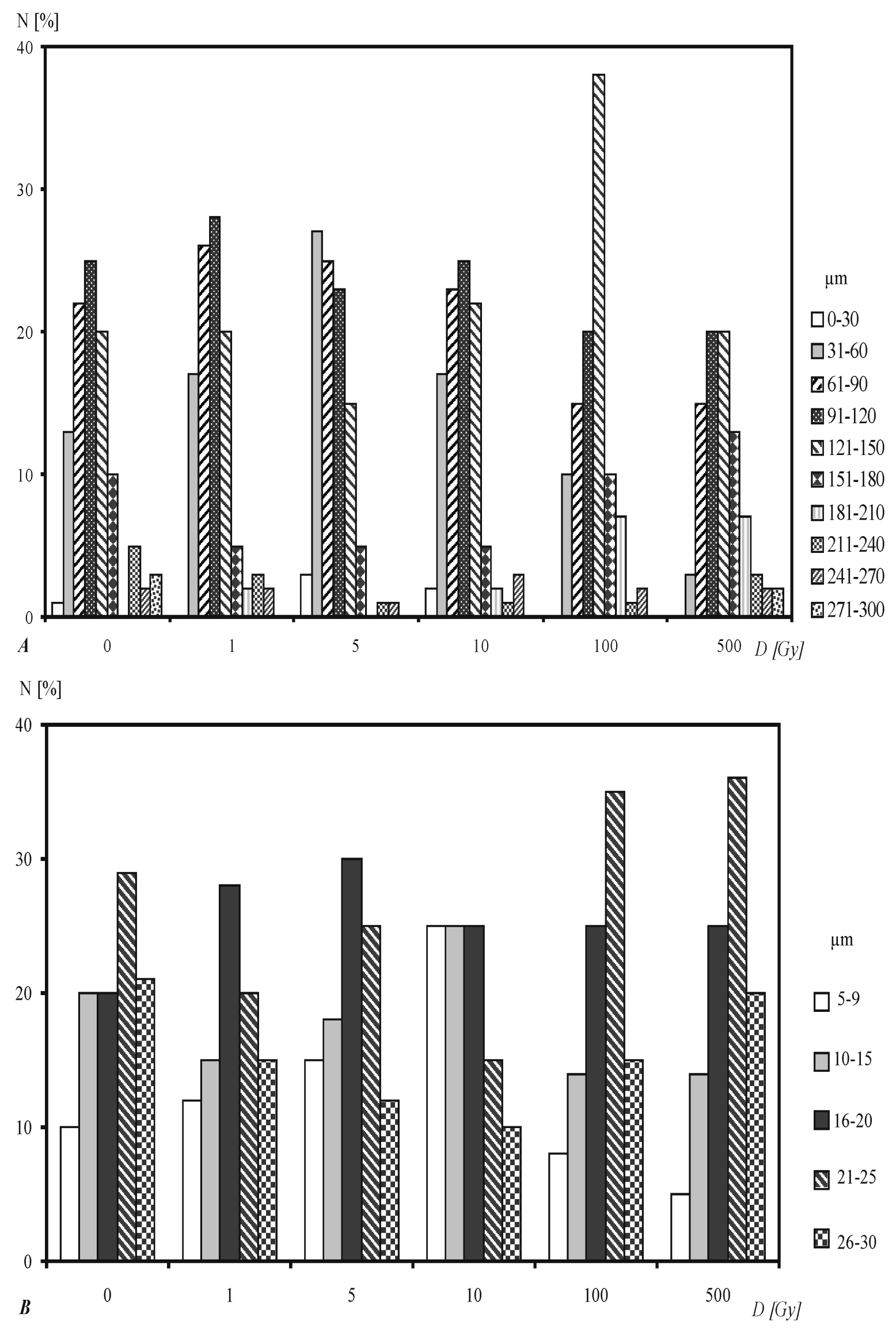

Fig.4. Statistical distribution of cells (A) and nuclei (B) for non-irradiated and irradiated peanut callus inoculums. Analyses were done for the random cell population (500 cells/nuclei) on the $28^{\text {th }}$ days after $\gamma$ - irradiation. Unit for cell length interval was $30 \mu \mathrm{m}$, unit for nuclei diameter was $5 \mu \mathrm{m}$ 
Stimulation doses had higher protein content compared to the control during all cultivation. This confirmed results obtained for mass increment (Fig. 1B). A high concentration of soluble proteins was detected after 48 hours for the dose $\mathrm{D}=500 \mathrm{~Gy}$. This effect is probably the result of two parallel processes, higher activity of reparation enzymes (products of late and very late genes) and degradation processes connected with death cells.

Cells and nuclei polymorphism showed that in the stationary phase of the growth (672 hours after irradiation), callus inoculums irradiated with stimulating dose of $\gamma$-radiation shifted their maximum in the cell population to the shorter parameters. What was indicated on the lower level of polyploidy in the irradiated peanut cell population? The presence of the small and very length cells indicated on the two very different cell groups. Small, nearly round cells were actively proliferated to the opposite very long cells with the small nucleus. These cells had a yellow-orange color and their metabolisms answered to aging. Color changes can be affected with the peanut lectins synthesized as a result of aging. The number of larger cells was indicated for the callus inoculums irradiated with the doses D 100 and $500 \mathrm{~Gy}$. Poisson distribution can describe the statistical distribution of the cell length and nuclei diameter in the control callus.

\section{CONCLUSIONS}

1) Doses of $\gamma$-radiation applied on the partially synchronised peanut calli cultures affected gene expression in a dependance of used doses and postradiation interval.

2) Doses $D \geq 100$ Gy affected: gene expression and some genes transcription that was shown by missing proteins in the patterns during all studied postradiation time (missing protein $\mathrm{Mr} \sim 65,72,85$ and $95 \mathrm{kDa}$ ); growth processes in lag and exponential phase of the growth; $\mathrm{LD}_{50}$ received value $250 \pm 50 \mathrm{~Gy}$; changes in the content of secondary metabolites in the stationary phase of the growth.

3) Doses of $\gamma$-radiation higher than 10 Gy activated synthesis of the proteins from the apoptosis pathway in two waves, at $24-48^{\text {th }}$ and $672^{\text {nd }}$ hours after irradiation.

4) Doses of $\gamma$-radiation lower than 10 Gy decreased both level of polyploidy and cell polymorphism of peanut callus culture long-term cultivated in vitro conditions.

5) Doses with stimulating effect on the growth processes, $\mathrm{D} \in<1,10>$, affected content of proteins connected with cdc-2 complex and reaction of phosphorylation/dephosphorylation.

6) Doses of $\gamma$-radiation higher than 10 Gy affected quantitative content of proteins from the lectine group.

7) Changes in the content of auxin and cytokinin binding proteins in various postradiation intervals indicated the possibility of the participation of exogenous growth regulators in the postradiation repair mechanisms after irradiation.

\section{ACKNOWLEDGEMENT}

We would like to express our thanks to prof. Dr. E.A. Krasavin (JINR Dubna, Russian) for the possibility to make our experiments with $\gamma$-rays.

This work was supported by Slovak Grant Agency Vega, project N0 1/9152/02.

\section{REFERENCES}

Awa A.A., T. Sofani, T. Honda, M. Itoh, S. Nereishi, M.Otaka: Relationship between the radiation dose and chromosome aberetions in atomic bomb survivors of Hiroshima and nagasaki. J. Radiat. Res. 19: 126-140, 1978.

Bradford M.R.: Rapid and sensitive method for the quantification of microgram quantities of protein utilizing the principles of protein dye binding. Annal. Biochem. 72: 248-254, 1976.

Blekkenhorst G.and M. Keraan: Effect of radiation and $\gamma$-linolenic acid on cell cycle progression of TKG-lymphoblastic and U937 myelomonocytic cells in vitro. Radiobiology II, www.up.ac.za/ saapmb38, 2003.

Eidus L.Ch.: Physics and chemical bases of radiation biology and radio-protection (In Russian) Moscow, Atom Publ. pp. 216, 1979.

Gacek E., E. Hlinková, E.N. Ismailova: Study of radiosensitivity and growth dynamic of Crepis capillaris, Haplopappus gracilis and Phasoleus vulgaris calli cultures after $\gamma$-irradiation. Preprint JINR, Dubna, P19-03-503: 1-10, 1983.

Govorun R.D., E. Lukášová, S. Kozubek, M.V. Repin, E.A. Krasavin, V. Kroha: Induction of aberation in human lymphocytes by $\gamma$-rays and heavy ions. Preprint JINR Dubna: E 19-98-31, 1-20, 1998.

Hai H., A. Hahnel, M.H. Hardy, W.D. Black: p53 protein expression and concurrent apoptosis induced by $\gamma$-irradiation or N-metyl-N-nitro sourea in normal and p53 mutant mouse hair follicles Eur. J. Derm. 7: 32-37, 1997. 
Hérouart D., M. Van Montagu, D. Inzé: Redox-activated expression of the cytosolic copper/zinc superoxid dismutase gene in Nicotianum. Proc. Natl. Acad. Scie. USA 90: 3108-3112, 1993.

Hermeking H., C. Lengauer, K. Polyak, T.C. He, L. Zhang, S. Tiangaling, K.W. Kinzler, B. Vogelstein: 14-3-3 sigma is a p53 regulated inhibitor of G2/M progression. Moll. Cell. 1: 311, 1997.

Hlinková E.: Effect of different doses of $\gamma$-radiation on tissue cultures in vitro. Acta FRN Univ. Genet. 20: 13-21, 1989.

Hlinková E.: Cytogenetic and morphogenic changes in callus culture of Haplopappus gracilis (Nutt.) caused by various factors. Acta FNR Univ. Genet. 21: 13-21, 1990.

Hlinková E. and A. Belková: Influence of 3-benzyloxycarbonylmethyl-2-benzothiazolinone on the mitotic cycle and its parameters of Vicia sativa L. cv. Fatima. Biologia (Bratislava), 46: 647-655, 1991

Hlinková E., M. Sýkora, Z. Šubr: Soluble protein patterns in barley infected with the barley powdery mildew (Erysiphe graminis f.sp. hordei Marchal). Agriculture 41: 597-613, 1995.

Koltovaya N.A., I.P. Arman, A.B. Devin: Gene and the radiation sensitivity of Saccharomyces cerevisae. Yeast 14: 133-146, 1998.

Knehr S., H. Zitzelsberger, H. Braselmann, E. Schmidt, M. Bauchinger: Analyses for DNA proportional distribution of radiation-induced chromosome aberration in human chromosomes using florescence in situ (FISH). Int. J. Rad. Biol. 65: 683-690, 1994.

Kulaeva O.N., N.N. Karavajko, S.Y. Selivankina, I.E. Moshkov, G.V. Novikova, Y.V. Zemlyachenko, S.V. Shipilova, E.M Orudgev: Cytokinin signalling systems. Plant Growth Reg. 18: 29-37, 1996.

Laemmli U.K.: Cleavage of of structural proteins during the assembly of the head of bacteriophage T4. Nature 227: 680-685, 1970.

Miao H., B.R. Wei, D.M. Pechl, Q. Li, T. Alexandrou, J.R.. Schelling, J.S. Rhim, J.R. Sedor, E. Burnett, B. Wang: Activation of
EphA receptor tyrosine kinase inhibits the Ras/MAPK pathway. Natl. Cell Biol 3: 527-530, 2001.

Murashige T. and F. Skoog: A revised medium for rapid growth and bioassay with tobacco tissue culture. Plant Physiol. 15: 473-479, 1962.

Nelms B., R.S. Maser, J.F. MacKay, M.G. Lagally, J.H.J Petrini: In situ visualization of DNA double-strand break repair in human fibroblast. Science 280: 590-592, 1998.

Nesterenko M.V., M. Tilley, S.J. Uptán: A simple modification of Blum's silver stain method allows for 30 minute detection of proteins in polyarcylamide gels. J. Biochem. Bioph. Meth. 28: 239-242, 1994.

Ritter S., E. Nasonova, M. Scholz, W. KraftWeyerather, G. Kraft: Comparison of chromosomal damage induced by X-rays and Ar ions with LET of $1940 \mathrm{keV} / \mu \mathrm{m}$ in $\mathrm{G} 1$ of V79 cells. Int. J. Radiat. Biol. 69: 155-166, 1996.

Roos W.P., A. Binder, L. Bohm: The dose dependence of G2 delay. Radiobiology II, ww.up.ac.za/saapmb 38, 2003.

Smith J.A.: Analysis of protein. In Ausubel F.M. et al. (eds.) Current Protocols in Molecular Biology, J.Willey \& Sons, CambridgeChichester-Toronto, pp. 10.0.3-10.3.11, 1988.

Takenaka K., T. Moriguchi, E. Nishida: Activation of the protein kinase p38 in the spindle assembly checkpoint and mitotic arrest. Science 280: 599602, 1998.

Timofeev-Resovski N.T., V.I. Ivanov, V.I. Korogodin: Application of microdosimetry and their principles in radiobiology (In Russian). Moscow, Atom Publ. 187: 1968.

Yin Y., T. Terauchi, G.G. Solomon, S. Aizawa, P.N. Rangarajan, Y. Yazaki, T. Kadowaki., J.C. Barreth: Involvement of p85 in p53-dependent apoptotic response to oxidative stress. Nature 391: 707-710, 1998.

Yin.Y., G.G. Solomon, C. Deng, J.C. Barreth: Differential regulation of $\mathrm{p} 21$ and $\mathrm{Rb}$ in cellular response to oxidative stress. Mol. Carcino. 24: $15-24,1999$.

\section{Address:}

Elena Hlinková, Department of Genetics, Faculty of Natural Sciences, Comenius University, Mlynská dolina B-1, 84215 Bratislava, Slovakia; hlinkova@fns.uniba.sk 